\title{
The Effect of Breastfeeding Education Given to Mothers in the Accompanying Mother Unit on the Attitude and Knowledge of Feeding
}

\author{
Refakatçi Anne Ünitesinde Kalan Annelere Verilen Eğitimin Annelerin \\ Beslenme Tutumu ve Bilgisi Üzerine Etkisi
}

Gülşah Kös Aksin' ${ }^{1}$ Burcu Kayhan Tetik ${ }^{* 2}$

\begin{abstract}
Background: In this study, we examined the breastfeeding attitudes of mothers whose babies are in intensive care unit and the change of thought, after breastfeeding training given to mothers during they were staying as accompanying mothers. Methods: This study was conducted on the mothers whose babies were hospitalized in the neonatal intensive care unit between May and July 2019. Before the training entitled "The Importance of Breastmilk and Breastfeeding" was given to mothers during their babies were intensive care unit, a face-to-face interview questionnaire and the IOWA Infant Feeding Attitude Scale (IIFAS) were applied. After the training, IIFAS was applied to the mothers again. Results: A total of 51 mothers participated in our study. The mean age of the mothers was $27.77 \pm 5.8$ years. The mean IIFAS score of the mothers was $66.35 \pm 5.11$ before the training and $74.5 \pm 5.55$ after the training. While only $15(31.3 \%)$ of the mothers had an intention of breastfeeding before the training, 40 mothers $(83.3 \%)$ had an intention of breastfeeding, after the training. We observed a significant increase in the mean IIFAS score after the training. Conclusion: When we compare the attitudes of mothers, regarding breastfeeding their babies before and after breastfeeding training, it was observed that the trainings positively affected their attitudes. Growing healthy generations can only be achieved by feeding with breast milk and increasing the rate of breastfeeding can be achieved by increasing the awareness in the society.
\end{abstract}

Key words: Breast milk, education, newborn, IOWA, feeding attitude

ÖZET

Amaç: Bu çalışmada bebeği yoğun bakımda olan annelerin bebeklerini besleme tutumlarını incelemek, annelere verilen anne sütü ve emzirme eğitimi sonrası emzirme düsüncelerinde olan değișiklik araștırılmıștır. Yöntem: Calıșma Mayıs-Temmuz 2019 tarihleri arasında hastanemizde bebeği yenidoğan yoğun bakım ünitesinde yatan annelere verilen 'Anne Sütü ve Emzirmenin Önemi' eğitimi öncesi yüz yüze görüşme ile anket ve IOWA Yenidoğan ve Süt çocuğu Bebek Beslenme Tutum Ölçeği (I-YSÇBTÖ) uygulandı. Eğitim sonrası annelere I-YSÇBTÖ tekrar uygulandı. Çalışmada elde edilen bulgular değerlendirilirken, istatistiksel analizler için SPSS Statistics 22 programı kullanıldı. Anlamlılık $\mathrm{p}<0.05$ düzeyinde değerlendirildi. Bulgular: Çalışmamıza toplam 51 anne katıldı. Annelerin yaşlarının ortalaması $27.77 \pm 5.8$ yıl idi. Annelerin eğitim öncesi I-YSÇBTÖ puan ortalaması $66.35 \pm 5.11$ idi, eğitim sonrası puan ortalaması $74.5 \pm 5.55$ idi. Anne sütü ve emzirme eğitimi öncesi sadece 15 'i (\%31.3) emzirmeye meyilli grupta iken, eğitim sonrası 40 anne (\%83.3) emzirmeye meyilli grupta idi. Eğitim öncesi ve eğitim sonrası karşılaştırıldığında puan ortalamasında anlamlı bir fark olduğu gözlemlendi. Sonuç: Çalışmamızda anne sütü eğitimi öncesi ve sonrası karşılaştırdığımızda annelerin bebeklerini anne sütü ile besleme tutumunu pozitif yönde etkilediği gözlemlenmiştir. Sağlıklı bireylerin yetişmesi ancak anne sütü ile beslenerek artırılabilir. Anne sütü ile beslenme oranlarını artırmak ise toplumda anne sütü ile beslenme bilincini artırarak sağlanabilir.

Anahtar Kelimeler: Anne sütü, eğitim, yeni doğan, IOWA, beslenme tutumu

Received / Geliş tarihi: 22.02.2021, Accepted / Kabul tarihi: 18.09.2021

${ }^{1}$ Niyazi Misri No=110 Family Health Center, Malatya-TURKEY.

2 İnönü University Faculty of Medicine, Department of Family Medicine, Malatya-TURKEY.

*Address for Correspondence / Yazışma Adresi: Burcu Kayhan Tetik, İnönü University Faculty of Medicine, Department of Family Medicine, Malatya-TURKEY.

E-mail: drburcukayhan@hotmail.com

Kos Aksin G, Kayhan Tetik B. The Effect of Breastfeeding Education Given to Mothers in the Accompanying Mother Unit on the Attitude and Knowledge of Feeding. TJFMPC, 2021;15(4): 793-799.

DOI: $10.21763 /$ tjfmpc.883156 


\section{INTRODUCTION}

UNICEF and the World Health Organization (WHO) recommend that babies should be fed exclusively with breast milk in the first six-month, and breastfeeding should be continued with supplementary foods in addition to breast milk until the age of two years. ${ }^{1}$

The practice called "Baby-Friendly Hospital" was put into practice in 1992 by UNICEF and WHO to accomplish practical applications that will make the use of breast milk more widespread. In our country, the "Encouragement of Breastfeeding and Baby-Friendly Healthcare Organizations Program" has been implemented since 1991 with the support of UNICEF, to spread the exclusive use of breast milk within the first six months. ${ }^{2,3}$ Breastfeeding education provided for mothers during the prenatal period is one of the measures that will positively affect the mothers' attitudes towards breastfeeding their babies. Studies support this suggestion. The studies report that mothers who have received breastfeeding training are more strongly willing to breastfeed than those who have not received training. ${ }^{4}$

The Accompanying Mother and Education Units are the most appropriate setting to reach mothers who have not received breastfeeding training and who have not attended training programs due to preterm delivery. In this sense, the Companion Mother and Education Unit within our hospital is an important unit that provides breastfeeding training to mothers before their babies are discharged from the hospital. This study aims to observe the effectiveness of the breastfeeding training given to mothers with newborn babies, to investigate the attitudes of mothers towards feeding their baby, to emphasize the importance of breast milk, and to provide training to change the attitudes of mothers about feeding their babies and to prolong the duration of breastfeeding. In addition, it was aimed to prepossess the mothers who experience difficulty staying in the hospital before they could bond with their babies and change their nutritional attitudes in favor of breastfeeding.

\section{MATERIALS AND METHODS}

In this study applied all mothers whose babies were in the intensive care unit, staying in the Accompanying Mother and Education Unit within the İnönü University Faculty of Medicine and who participated voluntarily, between May-July 2019 were included. Ethical approval was obtained from İnönü University Scientific Research Publication Ethics Committee (Medical Sciences NonInterventional Clinical Research Ethics Committee) on 07.05.2019 with the registration number of 2019 / 9-22. Informed consent of mothers who agreed to participate in the study was obtained after they were given detailed information about the study. One of the mothers was excluded from the study because she was younger than 18 years old and 2 mothers could not complete training due to the health problems of their babies. A sociodemographic data form including information such as age, place of residence, educational status, and occupation and IOWA Infant Feeding Attitude Scale (IIFAS) were applied to the remaining 48 mothers, by face-to-face interview technique. A single researcher did the surveys. The trainings were given by the same training nurse. As a result, the data of a total of 48 mothers before and after breast milk training were analyzed statistically.

\section{IOWA INFANT FEEDING ATTITUDE SCALE (IIFAS)}

The IOWA Infant Feeding Attitude Scale (IIFAS) was developed by De La Mora and Russell in 1999. The Turkish validity and reliability study of the scale was conducted by Eksioglu et.al. ${ }^{6}$ The scale was designed to determine the attitudes of women about breastfeeding their babies and to determine the times and methods of feeding their babies..$^{5}$ The items of the scale are scored between $1=$ strongly agree and $5=$ strongly disagree. The first 9 items in the scale affirm breastfeeding and 8 items are reverse scored $(5=1 \ldots 1=5)$. The total attitude score on the scale ranges between 17 and 85 . Lower scale scores indicate that mothers tend to bottle-feed their babies and higher scores indicate that they tend to breastfeed their babies. ${ }^{5}$

\section{DATA ANALYSIS}

The statistical evaluation of the data was performed by using SPSS package program version 22.0. The normality of distribution was tested by the Shapiro Wilks test. Student t-test and Oneway Anova test were used to compare the data with normal distribution. Tamhane's T2 test and Tukey HDS test were used to determine the group that caused the differences. McNemar test was used to compare preand post-training values of the qualitative data. The data were expressed as a percentage, frequency, mean and standard deviation. Cronbach's alpha coefficient was calculated for the reliability of the scale. A value of $p<0.05$ was accepted as statistically significant.

\section{RESULTS}

The study was completed with 48 mothers. The mean age of the mothers was $27.77 \pm 5.8(18-40)$ years, $12(25 \%)$ were living in the village, $4(8.3 \%)$ were illiterate, and $39(81.3 \%)$ were housewives. We found that 22 of the mothers $(45.8 \%)$ had a single child and 28 of the babies $(58.3 \%)$ were premature. None of the mothers had received breastfeeding training. Only $5(10.4 \%)$ mothers had been able to contact with their babies as soon as they were born, while 43 (89.6\%) did not. Kangaroo care was applied 
to $3(6.3 \%)$ of the babies in the intensive care unit. The sociodemographic characteristics of the participants are given in Table 1.

\section{Table 1. General Data of Participants}

\begin{tabular}{|c|c|c|c|}
\hline & & Min-Max & Mean \pm SD \\
\hline \multirow[t]{2}{*}{ Age } & & $18-40$ & $27.77 \pm 5.8$ \\
\hline & & $\mathrm{n}$ & $\%$ \\
\hline \multirow[t]{3}{*}{ Place of residence } & Village & 12 & 25 \\
\hline & County & 7 & 14.6 \\
\hline & City center & 29 & 60.4 \\
\hline \multirow[t]{4}{*}{ Educational status } & Illiterate & 4 & 8.3 \\
\hline & Secondary school & 26 & 54.2 \\
\hline & High school & 9 & 18.8 \\
\hline & University & 9 & 18.7 \\
\hline \multirow[t]{2}{*}{ Occupation } & Housewife & 39 & 81.3 \\
\hline & Other & 9 & 18.7 \\
\hline \multirow[t]{2}{*}{ Number of children } & Single & 22 & 45.8 \\
\hline & More than one & 26 & 54.2 \\
\hline \multirow[t]{2}{*}{ Gender of the baby $(\mathrm{n}=51)$} & Female & 24 & 47.1 \\
\hline & Male & 27 & 52.9 \\
\hline \multirow[t]{2}{*}{ Time of delivery } & Preterm & 28 & 58.3 \\
\hline & Term & 20 & 41.7 \\
\hline \multirow[t]{2}{*}{ Was it a planned pregnancy? } & Yes & 33 & 68.8 \\
\hline & No & 15 & 31.3 \\
\hline Have you ever received breastfeeding treatment? & No & 48 & 100 \\
\hline \multirow{2}{*}{ Did you have a contact with your baby? } & Yes & 5 & 10.4 \\
\hline & No & 43 & 89.6 \\
\hline \multirow{2}{*}{ Was kangaroo care was applied to your baby? } & Yes & 3 & 6.3 \\
\hline & No & 45 & 93.7 \\
\hline
\end{tabular}

When the breastfeeding status was questioned, it was found that $6.3 \%$ of the babies received breast milk immediately after birth and $14.6 \%$ within the first hour. (Figure 1).

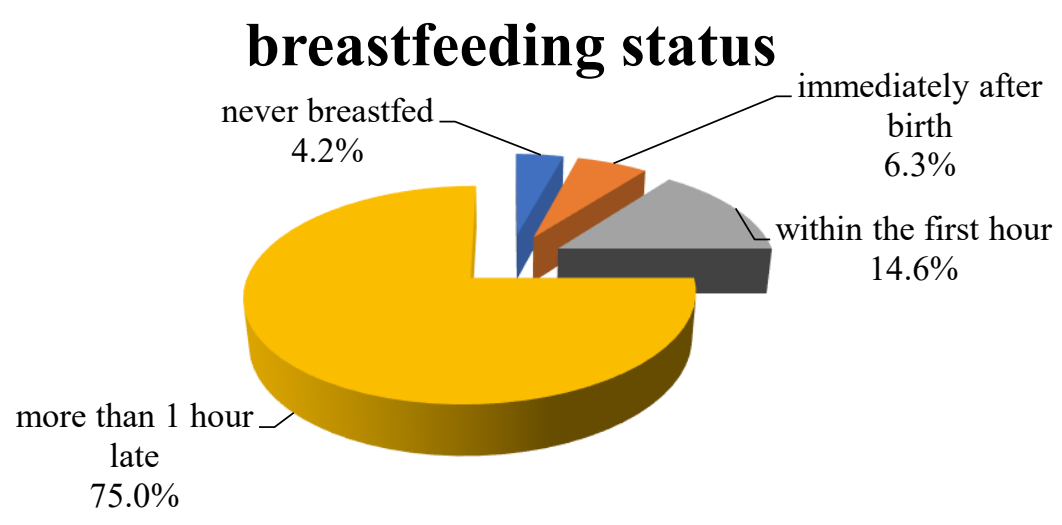

Figure 1. Chart of breastfeeding status at current birth 
The distribution of the responses given by the mothers to IIFAS questions, before and after the training is given in table 2 .

Table 2. Distribution of the responses given by the mothers to IIFAS questions, before and after the training

\begin{tabular}{|c|c|c|c|c|c|}
\hline \multirow[t]{2}{*}{ IIFAS (Before treatment) } & $\begin{array}{l}\text { Strongly } \\
\text { Agree }\end{array}$ & Agree & Undecided & Disagree & $\begin{array}{l}\text { Strongly } \\
\text { disagree }\end{array}$ \\
\hline & & n (\%) & n (\%) & n (\%) & \\
\hline $\begin{array}{l}\text { 1) The benefit of breast milk continues until the baby is cut off from } \\
\text { breast milk }\end{array}$ & $8(\% 16.7)$ & $30(\% 62.5)$ & $7(\% 14.6)$ & $3(\% 6.3)$ & $0(\% 0)$ \\
\hline 2) Feeding with formula is more suitable than breast milk. & $0(\% 0)$ & $0(\% 0)$ & $0(\% 0)$ & $35(\% 72.9)$ & $13(\% 27.1)$ \\
\hline 3)Breastfeeding increases the bond between mother and baby. & $37(\% 77.1)$ & $11(\% 22.9)$ & $0(\% 0)$ & $0(\% 0)$ & $0(\% 0)$ \\
\hline 4) Breast milk is poor in iron & $0(\% 0)$ & $1(\% 2.1)$ & $12(\% 25)$ & $30(\% 62.5)$ & $5(\% 10.4)$ \\
\hline 5) Obesity is more common in babies fed with formula. & $5(\% 10.4)$ & $33(\% 68.8)$ & $3(\% 6.3)$ & $6(\% 12.5)$ & $1(\% 2.1)$ \\
\hline $\begin{array}{l}\text { 6) It is a better choice to feed the mother with formula when she } \\
\text { starts working. }\end{array}$ & $0(\% 0)$ & $7(\% 14.6)$ & $2(\% 4.2)$ & $35(\% 72.9)$ & $4(\% 8.3)$ \\
\hline $\begin{array}{l}\text { 7) Mothers who feed their babies with formula are deprived of } \\
\text { breastfeeding, which is the greatest pleasure of motherhood. }\end{array}$ & $11(\% 22.9)$ & $34(\% 70.8)$ & $2(\% 4.2)$ & $1(\% 2.1)$ & $0(\% 0)$ \\
\hline 8) Mothers should not breastfeed their babies in public places. & $7(\% 14.6)$ & $18(\% 37.5)$ & $4(\% 8.3)$ & $16(\% 33.3)$ & $3(\% 6.3)$ \\
\hline $\begin{array}{l}\text { 9) Babies fed with breast milk are healthier than babies fed with } \\
\text { formula. }\end{array}$ & $33(\% 68.8)$ & $15(\% 31.3)$ & $0(\% 0)$ & $0(\% 0)$ & $0(\% 0)$ \\
\hline 10) Obesity is more common in babies fed with breast milk. & $1(\% 2.1)$ & $8(\% 16,7)$ & $8(\% 16.7)$ & $27(\% 56.3)$ & $4(\% 8.3)$ \\
\hline 11) If the mother is breastfeeding, the father feels lonely. & $1(\% 2.1)$ & $8(\% 16.7)$ & $5(\% 10.4)$ & $27(\% 56.3)$ & $7(\% 14.6)$ \\
\hline 12) Breast milk is the ideal food for babies. & $36(\% 75)$ & $12(\% 25)$ & $0(\% 0)$ & $0(\% 0)$ & $0(\% 0)$ \\
\hline 13) Breast milk is better digested than formula. & $32(\% 66.7)$ & $16(\% 33.3)$ & $0(\% 0)$ & $0(\% 0)$ & $0(\% 0)$ \\
\hline 14) Formulas are as healthy as breast milk for the baby. & $0(\% 0)$ & $0(\% 0)$ & $5(\% 10.4)$ & $6(\% 12.5)$ & $32(\% 66.7)$ \\
\hline 15) Breast milk is more suitable than formula. & $28(\% 58.3)$ & $19(\% 39.6)$ & $1(\% 2.1)$ & $0(\% 0)$ & $0(\% 0)$ \\
\hline 16) Breast milk is cheaper than formula. & $26(\% 54.2)$ & $19(\% 39.6)$ & $0(\% 0)$ & $2(\% 4.2)$ & $1(\% 2.1)$ \\
\hline 17) If the mother smokes, she should not breastfeed her baby. & $1(\% 2.1)$ & $18(\% 37.5)$ & $11(\% 22.9)$ & $17(\% 35.4)$ & $1(\% 2.1)$ \\
\hline
\end{tabular}

\section{IIFAS (After treatment)}

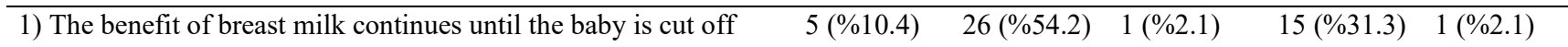
from breast milk

2) Feeding with formula is more suitable than breast milk.

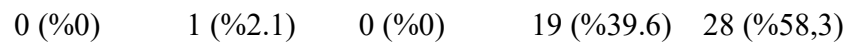

3) Breastfeeding increases the bond between mother and baby.

$45(\% 93.8) \quad 3(\% 6.3) \quad 0(\% 0)$

$0(\% 0) \quad 0(\% 0)$

4) Breast milk is poor in iron

$0(\% 0) \quad 1(\% 2.1) \quad 3(\% 6.3) \quad 20(\% 41.7) \quad 24(\% 50)$

5) Obesity is more common in babies fed with formula.

$20(\% 41.7) \quad 23(\% 47.9) \quad 1(\% 2.1) \quad 4(\% 8.3) \quad 0(\% 0)$

6) It is a better choice to feed the mother with formula when she $0(\% 0) \quad 0(\% 0) \quad 2(\% 4.2)$

$25(\% 52.1) \quad 21(\% 43.8)$ starts working.

7) Mothers who feed their babies with formula are deprived of $26(\% 54.2) \quad 20(\% 41.7) \quad 1(\% 2.1) \quad 1(\% 2.1) \quad 0(\% 0)$ breastfeeding, which is the greatest pleasure of motherhood.
8) Mothers should not breastfeed their babies in public places.
$1(\% 2.1) \quad 7(\% 14.6) \quad 2(\% 4.2)$
$16(\% 33.3) \quad 22(\% 45.8)$
9) Babies fed with breast milk are healthier than babies fed with formula.
$43(\% 89.6) \quad 5(\% 10.4) \quad 0(\% 0)$
$0(\% 0)$
$0(\% 0)$
10) Obesity is more common in babies fed with breast milk.
$1(\% 2.1) \quad 3(\% 6.3) \quad 1(\% 2.1)$
$28(\% 58.3) \quad 15(\% 31.3)$
11) If the mother is breastfeeding, the father feels lonely.
$2(\% 4.2) \quad 6(\% 12.5) \quad 2(\% 4.2)$
$23(\% 47.9) \quad 15(\% 31,3)$
12) Breast milk is the ideal food for babies.
$44(\% 91.7) \quad 4(\% 8.3) \quad 0(\% 0) \quad 0(\% 0) \quad 0(\% 0)$
13) Breast milk is better digested than formula.
$47(\% 97.9) \quad 1(\% 2.1) \quad 0(\% 0) \quad 0(\% 0) \quad 0(\% 0)$
14) Formulas are as healthy as breast milk for the baby.
$\begin{array}{lllll}0(\% 0) & 0(\% 0) & 3(\% 6.3) & 24(\% 50) & 21(\% 43.8)\end{array}$
15) Breast milk is more suitable than formula.
$44(\% 91.7) \quad 4(\% 8.3) \quad 0(\% 0) \quad 0(\% 0) \quad 0(\% 0)$
16) Breast milk is cheaper than formula.
$43(\% 89.6) \quad 3(\% 6.3) \quad 1(\% 2.1) \quad 1(\% 2.1) \quad 0(\% 0)$
17) If the mother smokes, she should not breastfeed her baby.
$3(\% 6.3) \quad 4(\% 8.3) \quad 1(\% 2.1)$
$25(\% 52.1) \quad 15(\% 31.3)$ 
The total IIFAS scores were between 55 and 79, with an average of $66.35 \pm 5.11$ and a Cronbach's alpha score of 0.665 before the training and were between 59 and 84 , with an average of $74.5 \pm 5.55$, and the
Cronbach's alpha score was 0.746 , after the training. We observed that IIFAS scores increased significantly after the training compared to before education (p: $0.000 ; \mathrm{p}<0.05)$ (Table 3$)$

Table 3. Evaluation of the mean IIFAS scores before and after the training

\begin{tabular}{llll}
\hline IIFAS & Min-Max & Mean \pm SD & Cronbach's Alpha \\
\hline \hline Total IIFAS score before the training & $55-79$ & $66.35 \pm 5.11$ & 0.665 \\
Total IIFAS score after the training & $59-84$ & $74.5 \pm 5.55$ & 0.746 \\
\hline $\mathrm{p}$ & & $0.000^{*}$ & \\
\hline $\mathbf{p}<\mathbf{0 . 0 5}$ Paired Samples t-test & &
\end{tabular}

\section{DISCUSSION}

It has been accepted worldwide that breastfeeding the baby exclusively, for the first six months, is the best in terms of the health of the mother and baby. However, it is estimated that only $39 \%$ of newborn babies are fed exclusively with breast milk for the first six months after birth. ${ }^{7}$ In the literature, the factors that affect the disposition of mothers to quit breastfeeding earlier, have been investigated. These factors include the mother's education level, the mother's need to return to working life, the delayed starting of breastfeeding, the lack of training about breastfeeding, given by healthcare personnel, the lack of support from the family, and giving the newborn baby water or sugary water instead of breast milk as the first food. ${ }^{8}$

There is no reliable scale to determine mothers' attitudes towards breastfeeding or feeding their babies by using formulas in our country. For this reason, studies on the attitudes of mothers about breastfeeding are not sufficient. The Turkish version of IIFAS, validity and reliability study conducted by Eksioglu et $\mathrm{al}^{6}$ in 2016, can be suggested as an effective measurement tool. The Turkish version of IIFAS was found to be a valid and reliable tool to examine the mothers' attitudes towards breastfeeding, statistically.

In our country, breastfeeding and breast milk training, which should be given to mothers especially during pregnancy, has been given to mothers after the 24th gestational week by the Family Health Centers. Studies on this subject have investigated the effects of breastfeeding training on mothers' attitudes and breastfeeding duration. ${ }^{10,11}$ Durand et al. ${ }^{12}$, in their study on prenatal education in Belarus, found that the attitudes of mothers about breastfeeding their babies in the education given to mothers increased from $14 \%$ to $28 \%$ after breastfeeding training. The importance of the education given to mothers during pregnancy is also emphasized in the studies. This education should be provided by expert teams who had been trained in the field. In Turkey, the rate of mothers receiving training during pregnancy is reported to be between $22.7 \%$ and $53.7 \% .^{13,14}$ In our study, most of the mothers stated that they did not receive breast milk and breastfeeding training during their pregnancy. This may be because most of the mothers who participated in our study gave birth prematurely and some of them have not been called for training, and those who had been called did not attend trainings and follow-ups.

IIFAS was developed specifically to measure the nutritional attitudes of expectant mothers. In addition, reliability studies have been conducted in various countries and in our country to be used to determine the nutritional attitudes of mothers, fathers, and others who provide care for babies. ${ }^{9}$ It is especially important to know the nutritional attitudes of pregnant women, to direct the expectant mothers who are planning to feed their babies with formula or who are indecisive to give breast milk.

In the study conducted by Wallis et $\mathrm{al}^{15}$., in Romania, the mean total IIFAS score of pregnant women was $63.3 \pm 2.6$, while the mean total score was $59 \pm 1.2$ in the study of Dungy et $\mathrm{al}^{16}$.'s, in Northern Ireland. In a study conducted by Küçükoglu et $\mathrm{al}^{17}$, in 2015 , on mothers whose babies were hospitalized in the neonatal intensive care unit, it was found that the mean total score of IIFAS $65.57 \pm 6.66$. In addition, Kuleyin et $\mathrm{al}^{18}$. investigated the validity and reliability of IIFAS in fathers in 2016 and suggested that IIFAS was a valid and reliable scale for Turkish fathers. In their study, the mean IIFAS total score of fathers was found to be $66.57 \pm 8.50$. In our study, the mean IIFAS score was $66.35 \pm 5.11$ before the training and $74.5 \pm 5.55$ after the training. The difference between the scores before and after the training was found to be statistically significant $(p<0.05)$. This result indicates the importance of training in directing the attitudes of mothers towards breastfeeding. To the 
best of our knowledge, there is no study comparing IIFAS scores before and after training.

In the study conducted by Wallis et $\mathrm{al}^{15}$, in Romania, it was determined that as the socioeconomic levels of pregnant women increased and the duration of breastfeeding of their previous babies increased, their scores on the IIFAS scale also increased. However, in a study conducted on pregnant women with low socioeconomic levels, by Dungy et al. in Glasgow ${ }^{16}$, it was reported that there was no relationship between the total score obtained from the scale and personal characteristics of the participants. On the other hand, it was determined that the total score obtained on the scale increased with the presence of a social environment with a positive attitude towards breastfeeding. In our study, we compared the attitudes of mothers towards breastfeeding, before and after training and found that the mean score increased significantly after the training, which indicates that training affected the nutritional attitudes of the mothers positively.

In the study conducted by Malini and Janell in 2008 , it was shown that the place of residence of mothers affected the breastfeeding attitude scores. ${ }^{19}$ In another study, the breastfeeding attitude score was found to be high in those living in a city center. ${ }^{20}$ In the study of Mwinilanaa and Kumi, in 2013, it was shown that income level and place of residence of mothers affect their breastfeeding attitudes. ${ }^{21}$ On the other hand, in the study of Yigitbas et al. ${ }^{22}$, although most of the families live in the city center, breastfeeding attitude scores are low. Kurnaz et $\mathrm{al}^{23}$., conducted a study on mothers in the early postpartum period, in 2014 and found that breastfeeding attitude scores of the mothers living in the city center were higher. Similarly, in our study, IIFAS scores of the mothers who lived in the city center were significantly higher compared to those living in counties and villages $(\mathrm{p}<0.05)$. Easy access to the health system, education level, and residence are thought to positively affect breastfeeding attitudes of mothers. It is also thought that communicating information about breastfeeding to mothers and those around them will positively affect attitudes towards breastfeeding.

It is very important to start breastfeeding as early as possible for continuity of breastfeeding. In one study conducted in Madagascar, breastfeeding in the first hour was investigated and the rate of starting breastfeeding in the first hour was found to be $78 \%$. In another study conducted in Nepal, the rate of starting breastfeeding in the first hour was found to be $3.4 \% .{ }^{24}$ Agboada et $\mathrm{al}^{25}$. in their study examined the effect of starting time of breastfeeding and the effects of time to start breastfeeding on the attitude towards continuing breastfeeding during the first six-month after delivery. In a study conducted in England, it was found that $77.7 \%$ of mothers started breastfeeding within the first hour after birth; however, it was suggested that the time of starting breastfeeding did not affect the attitude of breastfeeding during the first six months. In our study, the rate of breastfeeding in the first hour was found to be $7(14.6 \%)$. This rate, which is well below the average rate in Turkey, can be attributed to most of the mothers in our sample could not start breastfeeding because their babies were hospitalized in the intensive care unit.

\section{CONCLUSION}

In our study, we found that IIFAS scores statistically significantly increased after the training. In addition, the IIFAS scores of the mothers who live in the city center and whose education level is higher were statistically significantly higher. We suggest that women should be educated about the importance of breast milk and breastfeeding, starting from the period when pregnancy was planned and the training should be completed during pregnancy, as far as possible. We also suggest that emphasis should be placed on trainings provided in sections like Accompanying Mother Unit where mothers generally had not received training.

\section{CONFLICT INTERESTS}

The authors declare that there are no conflicts of interests

\section{REFERENCES}

1.World Health Organization. Infant and young child feeding Model Chapter for textbooks for medical students and allied health professionals. Geneva. Publication date: 2009, p:112.

2.Orun E, Yalcin SS, Madendag Y, Ustunyurt-Eras Z, Kutluk S, Yurdakok K. Factors associated with breastfeeding initiation time in a Baby-Friendly Hospital. Turk J Pediatr 2010;52:10-16. PMid:20402061.

3.Sağlık Bakanlığı. Ana ve çocuk sağlığı beslenme programı.http:// www.saglik.gov.tr/TR/belge/110965/ana-vecocuk beslenmesi programi . html ?vurgu $=$ bebek + dostu sayfasindan 22.08.2020 tarihinde erişilmiştir.

4. Qiu L, Zhao Y, Binns CW, Lee AH, Xie X. Initiation of breastfeeding and prevalence of exclusive breastfeeding at hospital discharge in urban, suburban and rural areas of Zhejiang China. Int Breastfeed J 2009; 4: 1-9.

5.De La Mora A, Russell DW. The Iowa Infant Feeding Attitude Scale: Analysis of reliability and validity. J Appl Soc Psychol 1999; 29: 2362-2380. 6.Ekşioğlu A, Yeşil Y, Turfan E. The Translation and Validation of the Iowa Infant Feeding Attitude 
Scale into Turkish Hemşirelikte Eğitim ve Araştırma Dergisi 2016; 13 : 209-15.

7.Küçükoğlu S, Çelebioğlu A. Effect Of NaturalFeeding Education on Successful Exclusive BreastFeeding and Breast-Feeding Self Efficacy of LowBirth-Weight Infants. Iranian J of Pediatrics 2014; 24: 49-56.

8.Toryiama ATM, Fujimon E, Palombo CNT, Duarte LS, Borges ALV, Chofakian CBN. Breastfeeding: what changed after a decade? Rev. Latino-Am. Enfermagem 2017;25:e2941 DOI: 10.1590/15188345.1858.2941 www.eerp.usp.br/rlae sayfasından 20.06.2020 tarihinde erişilmiştir.

9.Sittlington J, Stewart-Knox B, Wright M, Bradbury I, Scott JA. Infantfeeding attitudes of expectant mothers in Northern Ireland. Health Educ Res 2007; 22: 561-570.

10.Kurtuluş YE, Tezcan S. Bebeklerin beslenme alışkanlıkları, çocukların ve annelerin beslenme durumu. Türkiye Nüfus ve Sağlık Araştırması 2003; 12: 141-155.

11.Bağ Ö, Yaprak I, Halıcıoğlu O, Parlak Ö, Harputoğlu N, Astarcıoğlu G. Maternal Knowledge on Breastmilk and Psychosocial Factors lnfluencing Exclusive Breastfeeding İzmir Tepecik Eğitim Hastanesi Derg 2006; 16: 63-70.

12.Durand M, Labarere J, Brunet E, Pons JC. Evaluation of a training program for healthcare professionals about breastfeeding. Eur J Obstet Gynecol Reprod Biol 2003; 106: 134-8.

13.Kaynar TE, Dündar C, Canbaz S, Pekflen Y. Searching Breastfed Status of Children of 0-24 Months Applied to a University Hospital. C.Ü. Hemşirelik Yüksekokulu Dergisi 2006; 10: 1-6.

14.Tansuğ N, Yılmaz Ö, Kasırga E, et al. Breastfeeding practice in Manisa region. Ege Pediatr Bült 2006; 13: 155-161

15.Wallis AB, Brînzaniuc A, Chereches R, et al. Reliability and validity of the Romanian version of a scale to measure infant feeding attitudes and knowledge. Acta Pædiatrica 2008; 97: 1194-1199. 16.Dungy CI, McInnes RJ, Tappin DM, Wallis AB, Oprescu F. Infant feeding attitudes and knowledge among socioeconomically disadvantaged women in Glasgow. Matern Child Health J 2008; 12: 313-322. 17.Küçükoğlu S, Aytekin A, Ateşeyan S. Comparison of Breastfeeeding Tendencies and Breastfeeding Self-Efficacy of Mothers Whose Baby staying in Newborn Intensive Care Unit Balikesir Saglik Bil Derg 2015;4 : 71-78

18.Kuleyin A. Yenidoğan beslenmesinde Iowa Infant Feeding Attitudes Scale (IIFAS) ölçeğinin Türk babalarında geçerlik ve güvenirliğinin değerlendirilmesi. Uzmanlı Tezi. Ankara Üniversitesi Tıp Fakültesi, Halk Sağlığı Ana Bilim Dal1, Ankara, Türkiye. 2017, p:21-32.

19.Malini D, Janell L. Maternal breastfeeding attitudes: association with breastfeeding Intent and socio-demographics among urban primiparas. $\mathrm{J}$ of Community Health 2008; 33: 53-60.

20.Yılmaz C, Taşpınar A. Doğum Sonrası Erken Dönemde Ebeveynlere Verilen Emzirme Eğitiminin Bebeklerin İlk Altı Ay Anne Sütü Alma Durumuna Etkisi GÜSBD 2017; 6(3): 25 -34

21.Tampah-Naah AM, Kumi-Kyereme A. Determinants of exclusive breastfeeding among mothers in Ghana: a cross-sectional study. International breastfeeding Journal 2013; 8: 13.

22.Yiğitbaş Ç, Kahriman İ, Yeşilçiçek CK, Kobya Bulut H. About the Breast-Feeding Attitudes and Behavaur of the Mothers That Gave Birt in Trabzon GÜSBD 2012; 1: 49-59

23.Kurnaz D. The factors which effect the behavior and success of the mothers' breastfeeding in early postpartum period, Yüksek Lisans Tezi, Adnan Menderes Üniversitesi Sağlık Bilimleri Enstitüsü, Aydin 2014, 135

24.Mullany LC, Katz J, Li YM, et al. Breast-feeding patterns, time to initiation, and mortality risk among newborns in southern Nepal. J Nutr 2008; 138: 599603.

25.Agboado G, Michel E, Jackson E, Verma A. Factors associated with breastfeeding cessation in nursing mothers in a peer support programme in Eastern Lancashire. BMC Pediatr 2010;10: 3-7. 